\title{
Identification of a rat liver nuclear protein that binds to the enhancer core element of three animal viruses
}

\author{
Peter F. Johnson, William H. Landschulz, Barbara J. Graves, ${ }^{1}$ and Steven L. McKnight \\ Department of Embryology, Carnegie Institution of Washington, Baltimore, Maryland 21210 USA
}

This report describes the identification and purification of a nuclear protein from rat liver that binds selectively to DNA sequences associated with several animal virus enhancers. The binding activity was tracked by direct DNase I footprinting through four steps of biochemical fractionation. These procedures led to the identification of a polypeptide species exhibiting an apparent molecular weight of $20 \mathrm{kD}$ that accounts for enhancer binding activity. DNase I and dimethyl sulfate footprinting assays were used to examine the manner in which the purified protein binds to enhancer elements associated with SV40, murine sarcoma virus, and polyoma virus. The results of these assays indicate that the initial interaction established between the $20-\mathrm{kD}$ protein and each viral enhancer occurs via a common DNA sequence known as the enhancer core homology.

[Key Words: Enhancers; DNA-binding proteins; DNA-protein interactions; transcriptional regulation; rat liver; animal viruses]

Received December 15, 1986; revised version received and accepted January 9, 1987.

A surprising feature that has emerged from studies of transcriptional regulation in eukaryotic cells is the existence of regulatory DNA sequences, termed enhancers, that are capable of activating the expression of distantly linked genes. This property was observed initially for a 72-bp sequence that is repeated twice within the transcriptional control region of SV40 virus (Banerii et al. 1981; Moreau et al. 1981; Fromm and Berg 1983). More recent studies have shown that cis-regulatory elements with similar properties are associated with cellular genes (Banerii et al. 1983; Gillies et al. 1983; Queen and Baltimore 1983; Walker et al. 1983).

Although the mechanism by which long-range activation is achieved is not yet understood, several different lines of evidence have implicated the involvement of cellular factors that act in trans to potentiate enhancer utilization. For example, it has been observed that when a reporter gene linked to an enhancer is introduced into cultured animal cells, its expression can be reduced selectively by the inclusion of excess, unlinked copies of the enhancer DNA sequence (Scholer and Gruss 1984; Mercola et al. 1985). The results of these experiments have been interpreted to reflect in vivo competition for cellular factors that bind to enhancer DNA sequences. More direct evidence for the interaction between cellular factors and enhancers has come from experiments that mapped the accessibility of guanine residues within enhancers to alkylation by dimethylsulfate (DMS) in isolated nuclei. The results of two such studies revealed

1 Present address: Department of Cellular, Viral and Molecular Biology,
University of Utah Medical Center, Salt Lake City, Utah 84132 USA.
DMS protection-enhancement patterns within the intragenic enhancer of the mouse heavy-chain immunoglobulin gene in myeloma cells /which express the immunoglobulin gene) but not in fibroblasts (Church et al. 1985; Ephrussi et al. 1985). These altered patterns of DMS alkylation presumably reflect in situ contacts between cellular proteins and enhancer DNA sequences.

The involvement of cellular factors in enhancer activation has been demonstrated most clearly in the case of the glucocorticoid receptor. In an elegant series of experiments Yamamoto and colleagues have shown that the long terminal repeat (LTR) of mouse mammary tumor virus (MMTV) behaves as an enhancer (Chandler et al. 1983), and that the hormone inducibility of MMTV transcription is mediated by direct binding of the glucocorticoid receptor protein to the MMTV enhancer (Payvar et al. 1983).

Various lines of evidence have raised the provocative notion that enhancers may consist of multiple domains that together compose an element having distinct properties such as tissue or growth-state specificity. One line of evidence in support of this possibility was established by analyses of an extensive series of mutants of the SV40 enhancer (Zenke et al. 1986). This study identified several mutation-sensitive domains that were proposed to correspond to binding sites for cellular factors. In a related set of studies, Herr and colleagues mutated several sites within the SV40 enhancer which led to a growthdefective phenotype. Viable revertants were then selected, and DNA sequence analysis showed that the revertants carried duplications of specific segments of the enhancer (Herr and Gluzman 1985; Herr and Clarke 
1986). It was concluded that the sequences within these duplicated regions define distinct functional domains of the SV40 enhancer. These results, in concert with the gradual reductions in transcription efficiency observed as a result of progressive, unidirectional deletion mutagenesis of a number of enhancers (e.g., Queen and Stafford 1984; Graves et al. 1985), favor a multidomain model for enhancer organization.

If we are correct in assuming that enhancers consist of multiple domains, then cells in which a particular enhancer functions might be expected to express a set of DNA-binding proteins whose specificities match some or all of these domains. The most critical tool to determine the identities and functions of these proteins is the reconstitution of enhancer activity in vitro. Although some progress towards this goal has been made (Sassone-Corsi et al. 1984; Sergeant et al. 1984; Wildeman et al. 1984; Scholer and Gruss 1985), the magnitudes of enhancer effects observed in vitro have thus far been rather modest. Using an alternative approach, Maeda et al. (1986) found that a transcriptionally silent immunoglobulin gene present in mouse fibroblasts could be activated when the cells were microinjected with nuclear extracts derived from immunoglobulin-producing plasma cells. Finally, a number of recent reports have identified DNA-binding activities prepared as crude nuclear extracts that form sequence-specific interactions with various enhancers (Piette et al. 1985; Augereau and Chambon 1986; Davidson et al. 1986; Fuiimura 1986; Ohlsson and Edlund 1986; Ostapchuk et al. 1986; Peterson et al. 1986; Sen and Baltimore 1986; Wildeman et al. 1986).

A detailed understanding of the means by which enhancers activate expression of distantly located genes, as well as the basis for their cell-type specificity, will require the unambiguous identification and complete purification of cellular proteins that bind to enhancer domains. In this study we have identified and isolated a putative enhancer binding protein from rat liver nuclei.
The purified protein binds in a sequence-specific manner to domains shared by three viral enhancers (SV40, polyoma virus, and murine sarcoma virus). Each of these binding sites contains a common DNA sequence which has been termed the "enhancer core sequence" (see review by Sassone-Corsi and Borrelli 1986). We present the protocol that has been used to purify this enhancer binding protein, and identify a 20,000-dalton polypeptide as having the core binding activity.

\section{Results \\ An extract of rat liver nuclei contains enhancer binding proteins}

Several years ago we initiated experiments designed to test for rat liver nuclear proteins that bind to the murine sarcoma virus (MSV) LTR. Our approach involved the preparation of soluble extracts from purified rat liver nuclei, followed by direct DNA-binding assays for proteins capable of interacting with the LTR. The procedures that were devised to prepare and assay nuclear extracts, as well as the description and partial purification of an activity capable of binding to the CCAAT homology of the MSV LTR, have been published in a separate report (Graves et al. 1986).

During the course of these experiments we observed an activity capable of establishing a DNase I "footprint" (Galas and Schmitz 1978) over a region of the MSV LTR located several hundred base pairs upstream from the start site of transcription. This footprint occurred within a region of the LTR that exhibits enhancer activity (Levinson et al. 1982; Graves et al. 1985), and directly overlapped the sequence 5'-TGTGGTAAG-3' (the precise mapping of the footprinted domain will be presented in a subsequent section). The nonanucleotide sequence underlying the aforementioned footprint bears close homology to an enhancer core sequence [5'-TGTGG(AAA/ TTT/G-3'] that has been proposed on the basis of DNA sequence comparisons and in vitro mutagenesis experi-

Table 1. Purification of EBP20

\begin{tabular}{lcccccc}
\hline Fraction & Volume $(\mathrm{ml})$ & $\begin{array}{l}\text { Protein } \\
\text { concentration }(\mathrm{mg} / \mathrm{ml})\end{array}$ & $\begin{array}{l}\text { Total } \\
\text { protein }(\mathrm{mg})\end{array}$ & $\begin{array}{l}\text { Total } \\
\text { activity }(\mathrm{units})\end{array}$ & $\begin{array}{l}\text { Net } \\
\text { yield }(\%)\end{array}$ & $\begin{array}{l}\text { Specific } \\
\text { activity }(\mathrm{units} / \mu \mathrm{g})\end{array}$ \\
\hline RLNE & 47 & 3.0 & 141.0 & 188,000 & - & 1.3 \\
Heat soluble & 42 & 0.31 & 13.0 & 121,800 & 65 & 9.3 \\
DNA-Sepharose & 30 & 0.022 & 0.66 & 51,000 & 27 & 77 \\
FPLC Mono S & 8 & 0.014 & 0.112 & 16,000 & 8.5 & 140 \\
HPLC C & 1 & 0.0026 & 0.0026 & 1,400 & 0.7 & 540 \\
\hline
\end{tabular}

The data presented in the table are from a single preparation of rat liver nuclear extract which started with 700 grams (wet weight) of liver tissue. A unit of activity is defined as the amount needed to generate $50 \%$ occupancy of the polyoma virus enhancer core binding site under standard DNase I footprinting conditions (see Materials and methods). Each reaction contained approximately 5 fmoles of end-labeled polyoma virus enhancer DNA. Binding was quantitated by densitometric scanning of autoradiographic exposures of footprint gels according to the conventions described in detail by Graves et al. (1986). Protein was measured by the method of Bradford (1976) using bovine serum albumin as a standard, except for the HPLC C $_{4}$ fraction, in which the protein concentration was estimated by integrating the appropriate $230-\mathrm{nm}$ absorbance peak of the column elution profile. The molar concentration of EBP20 at which it half-maximally occupies the polyoma enhancer core sequence was calculated from the protein concentration measured in the HPLC $\mathrm{C}_{4}$ fraction. We assumed that half of the protein in the $1-\mathrm{ml} \mathrm{C}_{4}$ fraction was EBP20 $(1.3 \mu \mathrm{g})$ and determined that $0.7 \mu l$ of this fraction was required to establish $50 \%$ occupancy of the polyoma virus enhancer core sequence. Thus, if the protein binds as a 20,000 -dalton monomer, we calculate a binding constant of $9 \times 10^{-10} \mathrm{M}$. In calculating this value, we made the assumption that the concentration of unbound protein at the midpoint of the binding curve was essentially equal to the total EBP20 concentration in the reaction (Brenowitz et al. 1986). 
ments (Weiher et al. 1983; reviewed in Sassone-Corsi and Borelli 1986). Two particularly well-controlled experiments on the SV40 enhancer have shown that the core sequence is one of the most critical domains required for enhancer function (Herr and Gluzman 1985; Zenke et al. 1986). It seemed plausible, therefore, that the rat liver nuclear extract contained a DNA-binding protein bearing specificity for the enhancer core sequence, and that such a protein might play a role in enhancer function.

The SV40 and polyoma virus enhancers, like that of MSV, each contain an enhancer core homology. As a first step toward testing whether the rat liver protein was capable of interacting with each of these enhancers, we conducted footprint assays on the transcriptional control regions of SV40 and polyoma virus using the crude rat liver nuclear extract. These preliminary experiments revealed widespread DNase I footprinting of the SV40 enhancer not unlike published reports that utilized crude nuclear extracts derived from HeLa cells (Wildeman et al. 1986). A somewhat more limited set of interactions was observed in the case of polyoma virus. The transcriptional control region of polyoma virus has been shown to be separable into two independently functioning enhancers, each having distinctive host cell specificity (Herbomel et al. 1984). The rat liver nuclear extract established a DNase I protection pattern confined largely to the B domain (origin proximal) of the polyoma virus enhancer. In both SV40 and polyoma virus, the areas of DNase I protection established by the crude liver extract encompassed the enhancer core homology (data not shown).

While these observations were consistent with the presence of a DNA-binding protein that commonly interacts with each of the viral enhancers tested, the impure nature of the activity precluded the conclusion that a single protein was responsible for each footprint. Moreover, the presence of DNA-binding activities that protected domains adjacent to the enhancer core motifs, especially in the cases of MSV and SV40, presented difficulties in establishing the limits of the putative "core factor" footprint. Therefore, we undertook the biochemical purification of this activity using direct DNase I footprinting as an assay.

\section{Purification of an enhancer core binding protein}

After detecting the presence of a putative enhancer core binding activity in crude extracts of rat liver nuclei, we tested its sensitivity to protease digestion and heat inactivation. While protease treatment eliminated the activity, we were surprised to find that it was substantially unaffected when heated to $80^{\circ} \mathrm{C}$ for $5 \mathrm{~min}$. Since this treatment did inactivate a number of other DNAbinding proteins (as evidenced by the elimination of most other footprints on the SV40 and MSV LTR enhancers), and since it led to the precipitation of a majority of the protein mass in the crude rat liver extract, we chose to exploit the heat stability of the enhancer core binding activity as an initial step in its purification. As shown in Table 1, heat treatment facilitates the elim- ination of more than $90 \%$ of the protein present in the crude nuclear extract, yet leaves the majority of the enhancer core binding protein in a soluble and active state. DNA binding activity was monitored by a DNase I footprint titration assay (Graves et al. 1986) using the polyoma virus enhancer (see Materials and methods). Although this assay is subject to the artifactual effects of inhibitors that may be concentrated or eliminated at any step during purification, it approximates a quantitative assessment of the recovery of binding activity relative to protein concentration. According to these measurements we estimate that heat treatment leads to an eightfold increase in the specific activity of the enhancer core binding protein (see Table 1).

Heat-soluble protein was next factionated by affinity chromatography using a matrix consisting of salmon sperm DNA covalently coupled to cyanogen bromideactivated Sepharose 4B (see Materials and methods). Material was applied to the column at $0.1 \mathrm{M} \mathrm{KCl}$, washed at $0.2 \mathrm{M} \mathrm{KCl}$, and eluted by a linear $\mathrm{KCl}$ gradient. Protein elution was monitored by continuous UV absorption, and enhancer binding activity was tracked by performing DNase I footprint assays on individual column fractions. As illustrated in Figure 1, all detectable core binding activity bound to the DNA-Sepharose column and eluted between 0.4 and $0.6 \mathrm{M} \mathrm{KCl}$. Fractions exhibiting enhancer core binding activity were combined and the resultant pool was tested for activity by footprint titration on the polyoma virus enhancer. Since the vast majority of the protein flowed through the DNA-Sepharose column, or was eluted at $0.2 \mathrm{M} \mathrm{KCl}$, this purification step led to a substantial increase (roughly eightfold) in the specific activity of the core binding protein (see Table 1).

The DNA-Sepharose pool was dialyzed and then subjected to cation-exchange chromatography on an FPLC Mono-S column. The majority of the loaded protein bound to the column and eluted between 0.3 and $0.4 \mathrm{M}$ $\mathrm{KCl}$. DNase I footprint assays were performed on each column fraction and most of the enhancer core binding activity was found to elute between 0.4 and $0.5 \mathrm{M} \mathrm{KCl}$ (Fig. 2). Fractions containing core binding activity were combined and the pool was observed to have achieved a twofold increase in specific activity (see Table 1).

The material retrieved from the FPLC Mono-S column was applied directly to an HPLC $\mathrm{C}_{4}$ column and fractionated by reverse-phase chromatography (see Materials and methods). Protein was loaded onto the $\mathrm{C}_{4}$ column in the aqueous buffer that had been used to develop the Mono-S column, washed with buffered $20 \%$ acetonitrile, and then eluted with a linear gradient of $20-50 \%$ acetonitrile. Protein elution was tracked by UV absorption and core binding activity was again measured by DNase I footprinting. The major peak of UV absorbance occurred at roughly $33 \%$ acetonitrile, and this peak was coincident with the peak of DNase I footprint activity on the polyoma virus enhancer (Fig. 3). Although this purification step resulted in a substantial loss $(90-95 \%)$ of binding activity, it did achieve a threefold increase in specific activity (Table 1), and was later realized to be an important step in the identification of 


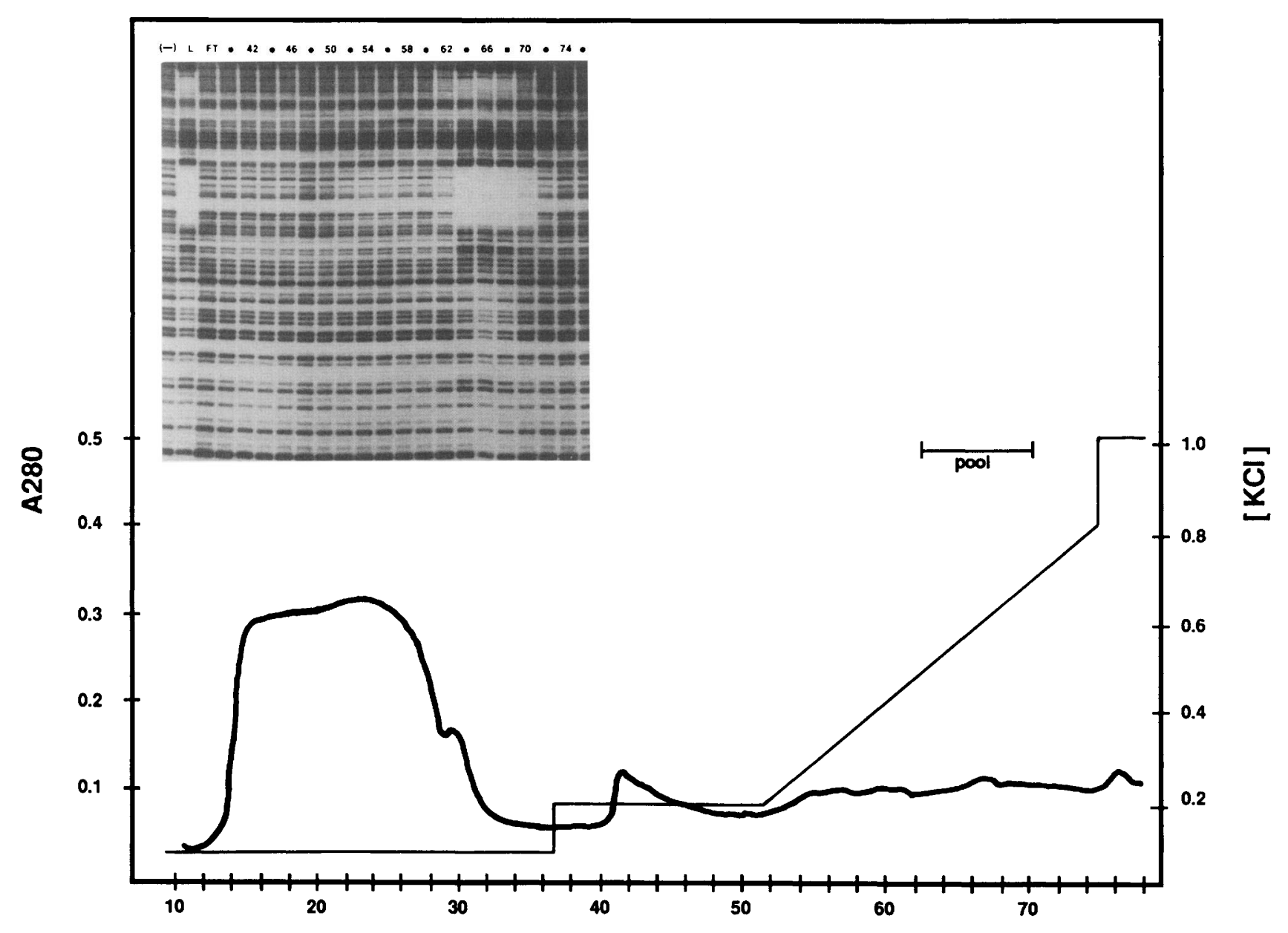

FRACTION NUMBER

Figure 1. Double-stranded DNA-Sepharose column chromatography. The heat-soluble component of rat liver nuclear extract was applied to a 15-ml DNA-Sepharose column equilibrated in $0.1 \mathrm{M} \mathrm{KCl}$ buffer. After loading, the column was washed with $0.2 \mathrm{M} \mathrm{KCl}$ and then developed with a linear gradient from 0.2 to $0.8 \mathrm{M} \mathrm{KCl}$. Protein concentration was monitored by continuous absorbance at $280 \mathrm{~nm}$. Five-microliter aliquots of alternate fractions were assayed by DNase I footprinting using the polyoma virus B enhancer probe (inset). (-) indicates a control DNase I reaction carried out without added protein; $L$ and FT refer to the load and pooled flowthrough (numbers 12-32) fractions, respectively. Fractions containing enhancer binding activity (numbers $62-70$ ) were pooled as indicated.

the polypeptide responsible for the enhancer core binding activity (see subsequent section). In combination, the four steps that were used to purify the putative enhancer core binding protein resulted in a $0.7 \%$ final yield and a 400-fold increase in specific activity.

\section{Identification of a polypeptide that accounts for enhancer core binding activity}

The ultimate goal of this study was to identify the protein species that accounts for the enhancer core binding activity observed initially in crude rat liver nuclear extracts. To this end we examined, by SDS-polyacrylamide gel electrophoresis, the protein species present in pooled fractions at each stage of purification. As shown in Figure 4, the most purified fraction of the enhancer core binding activity (fraction 18 from the HPLC $\mathrm{C}_{4}$ column shown in Fig. 3) contains a major polypeptide species that exhibits an electrophoretic mobility corresponding to an apparent molecular mass of 20,000 daltons. There were several indications that this $20-\mathrm{kD}$ species might account for the core binding activity. Most importantly, its concentration relative to other protein species increased at each stage of purification. While there are clearly other polypeptide species in the most purified sample (HPLC $\mathrm{C}_{4}$ fraction 18), most of them do not show consistent increases in proportional abundance during the various purification steps (e.g., the three polypeptides that exhibit apparent molecular weights of $35-40 \mathrm{kD}$ ).

To test definitively whether the $20-\mathrm{kD}$ polypeptide accounts for the enhancer core binding activity, we excised it and other candidate bands from an SDS-polyacrylamide gel, recovered each protein species by electroelution, and tested the isolated polypeptides for enhancer binding activity. While the procedures that were used to perform this test are presented in detail in Materials and methods, briefly, they included the following steps. Excised slices of polyacrylamide corre- 


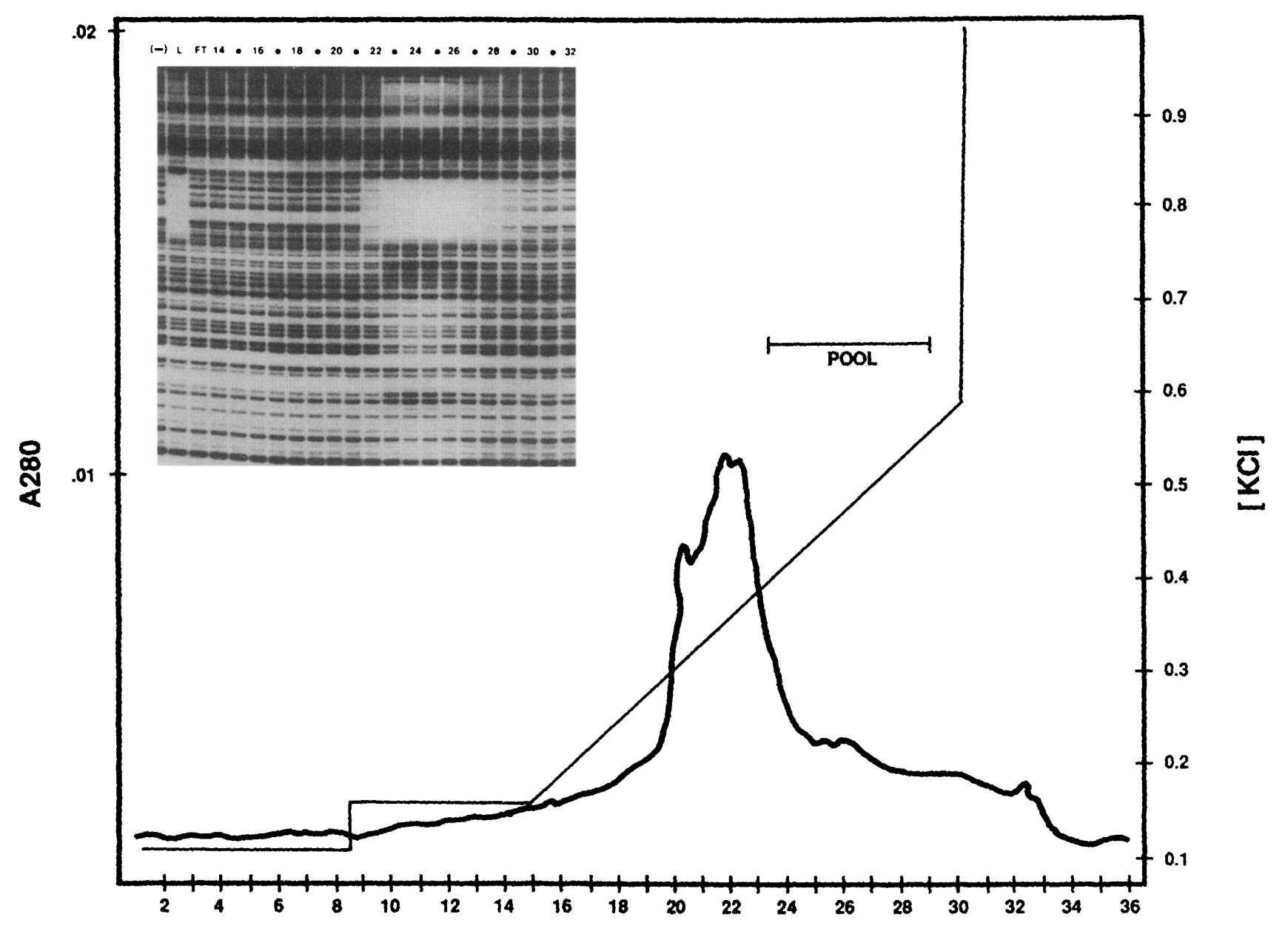

FRACTION NUMBER

Figure 2. FPLC Mono-S cation-exchange chromatography. The pool of activity from the DNA-Sepharose column was dialyzed to reduce the $\mathrm{KCl}$ concentration to $0.1 \mathrm{M}$ and applied to a $1-\mathrm{ml} \mathrm{FPLC} \mathrm{Mono-S} \mathrm{column} \mathrm{(Pharmacia).} \mathrm{After} \mathrm{loading,} \mathrm{the} \mathrm{column} \mathrm{was} \mathrm{washed}$ with buffer containing $0.15 \mathrm{M} \mathrm{KCl}$, and then developed with a linear gradient from 0.15 to $0.6 \mathrm{M} \mathrm{KCl}$. Protein concentration was monitored by absorbance at $280 \mathrm{~nm}$. Five-microliter aliquots of each fraction were assayed by DNase I footprinting for the ability to bind to the polyoma virus enhancer (inset). Symbols are the same as described in Fig. 1.

sponding to protein bands visible after Coomassie Blue staining were introduced into an electroelution chamber as described by Hunkapiller et al. (1983). Following electroelution and acetone precipitation, each protein sample was subjected to a procedure designed to facilitate renaturation of the DNA-binding activity (Hager and Burgess 1980; Briggs et al. 1986). This procedure involved resuspension of the precipitated protein in $6 \mathrm{M}$ guanidine hydrochloride and dialysis to remove the guanidine gradually. The samples were then tested for enhancer core binding activity by DNase I footprinting. When isolated in this manner, the $20-\mathrm{kD}$ polypeptide exhibited strong core binding activity (see Figs. 5-7), and none of the larger polypeptide species exhibited any core binding activity. We did observe very weak levels of core binding activity for several of the minor polypeptides that migrated faster than the $20-\mathrm{kD}$ species /data not shown). Although no firm conclusions can be made at this point as to the nature of these minor species, we suggest that they may represent proteolytic products of the $20-\mathrm{kD}$ polypeptide that retain their DNA binding domains.

We realize that the formal possibility exists that a minor polypeptide species, hidden by the more abundant $20-\mathrm{kD}$ protein, actually accounts for the core binding activity. However, the simplest interpretation of the results presented thus far holds that the $20-\mathrm{kD}$ polypeptide is responsible for the binding activity that was initially detected in crude nuclear extracts. We therefore tentatively identify the $20-\mathrm{kD}$ polypeptide as the enhancer binding protein, and term it EBP20.

\section{DNA-binding properties of purified EBP2O}

The availability of gel-purified EBP20 facilitated an assessment of its binding specificity in the absence of contaminating DNA binding proteins. Figures 5, 6, and 7 show the DNase I protection patterns generated by 


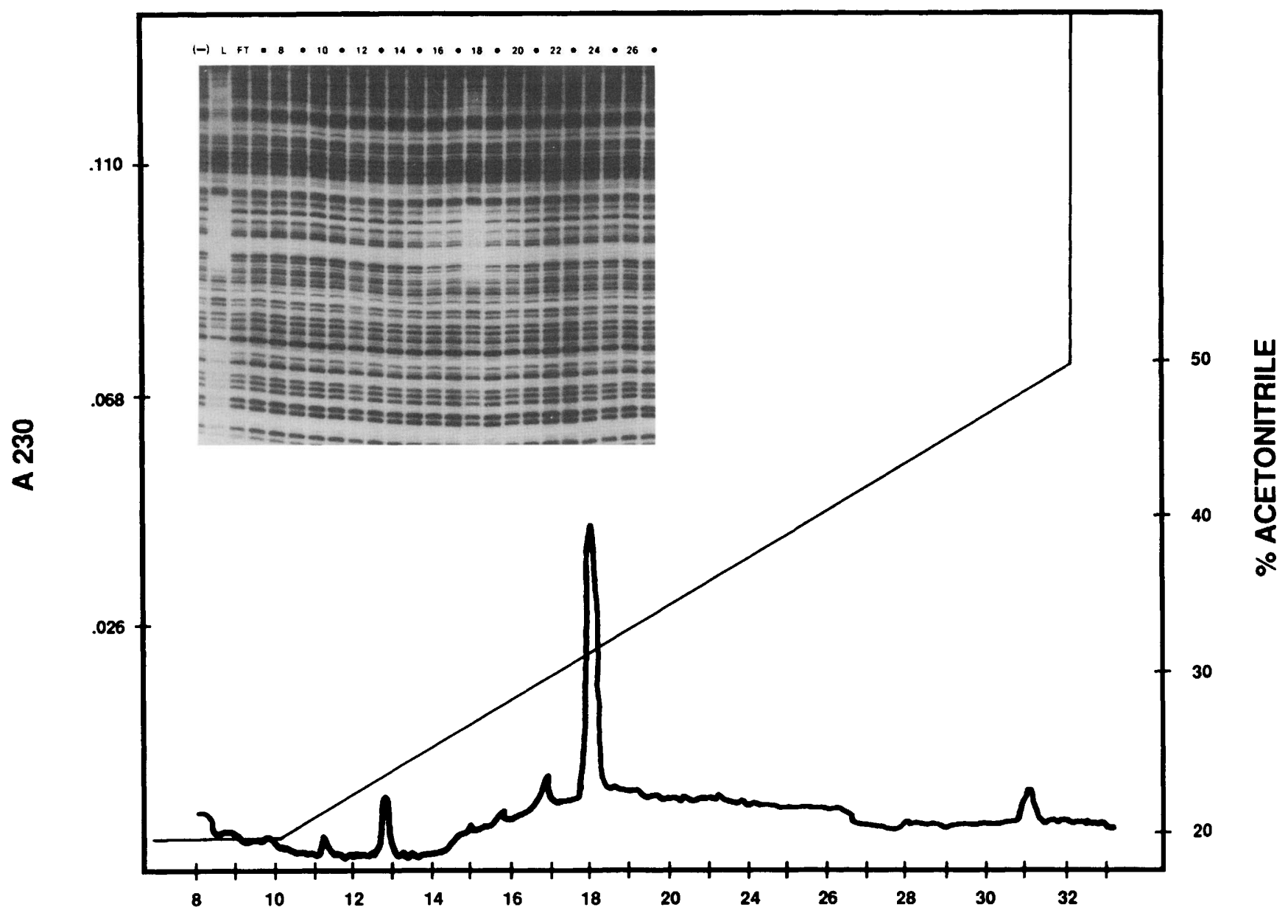

FRACTION NUMBER

Figure 3. Reverse-phase HPLC $\mathrm{C}_{4}$ chromatography. Active fractions from the Mono-S column were pooled and applied directly onto a $100 \times 2.1-\mathrm{mm} \mathrm{C}_{4}$ HPLC column. After loading, the column was washed with $20 \%$ acetonitrile in $0.4 \% \mathrm{~N}$ morpholinium acetate (NEMAC) ( $\mathrm{pH} 6.5$ ). The column was then developed with a linear gradient of $20-50 \%$ acetonitrile in $0.4 \%$ NEMAC (pH 6.5 ). Protein concentration was measured by continuous absorbance at $230 \mathrm{~nm}$. Ten microliters of each fraction was assayed by DNase I footprinting with the polyoma virus enhancer (inset). Symbols are as described in the legend to Fig. 1.

EBP20 on the enhancers of MSV, SV40, and polyoma virus, respectively. In each case DNA fragments carrying the enhancer were end-labeled with ${ }^{32} \mathrm{P}$ both by replacement of the $5^{\prime}$ phosphate and by fill-in extension from the $3^{\prime}$ hydroxyl at the same terminus. This enabled direct comparison of the manner in which EBP20 interacted with both DNA strands of each enhancer. Radiolabeled DNA probes were incubated with varying amounts of gel-purified EBP20 ranging from 1.5 to 22.5 $\mathrm{ng}$, and the positions of protein-DNA contacts were determined by DNase I digestion. In addition to DNase I footprint titrations on each DNA strand, dimethyl sulfate (DMS) alkylation assays were carried out using an EBP20 concentration of $30 \mathrm{ng}$ per reaction. Finally, each enhancer-bearing DNA fragment was subjected to chemical sequence analysis so that the DNase I and DMS footprint patterns could be precisely aligned with respect to the DNA sequence.
The patterns of interaction of EBP20 on each of the three viral enhancers are complex, especially when excess amounts of protein were included in the footprint reaction. The binding pattern was perhaps simplest on the MSV enhancer (Fig. 5). At low protein concentrations $(1.5-3.0 \mathrm{ng})$ EBP20 interacts with a single domain within each of the 75-bp repeats that define the MSV enhancer (designated by the solid boxes shown between the DNase I and DMS footprints|. This domain corresponds precisely with the location of the enhancer core sequence, and it is in exactly this same region that EBP20 causes alterations in the pattern of DMS alkylation. Specifically, DMS protections were observed at G residues that constitute the second and fifth residues of the nonanucleotide sequence ( $5^{\prime}$-TGTGGTAAG- $3^{\prime}$ ), and hyperalkylation was observed at the $G$ residue which constitutes the fourth residue of the nonanucleotide. At higher EBP20 concentrations, the DNase I protection 


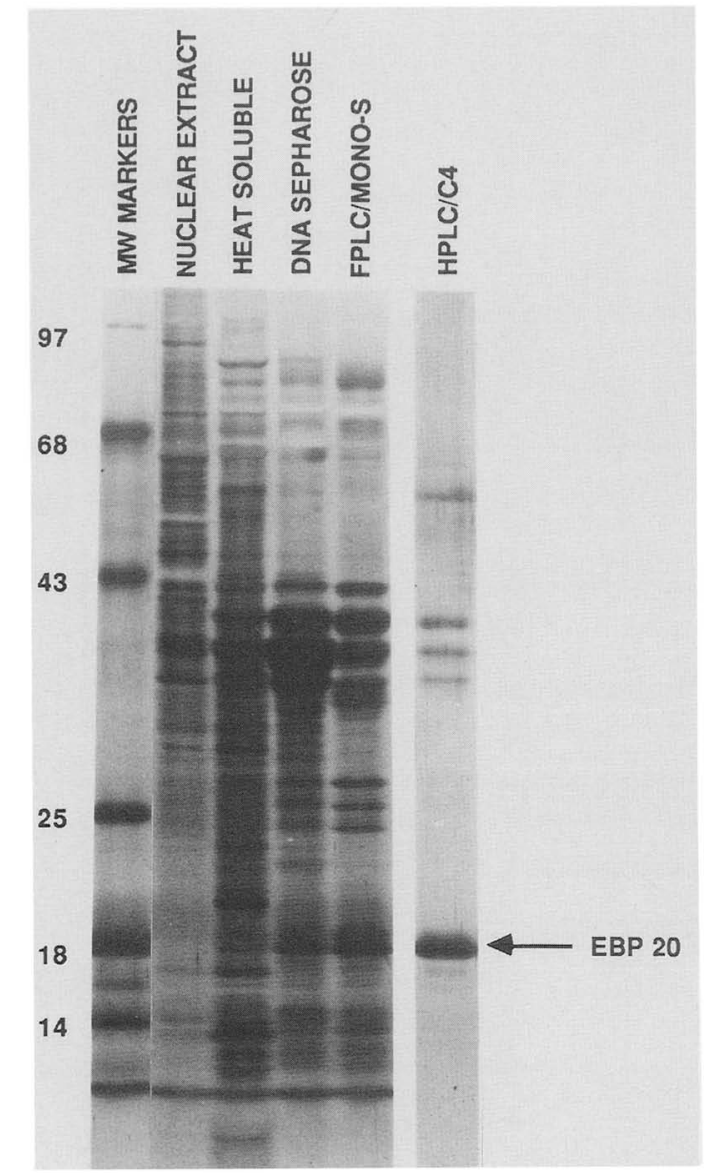

Figure 4. SDS-polyacrylamide gel analysis of protein fractions. Protein pools at every stage of the purification procedure (see Figs. 1-3) were analyzed by SDS-polyacrylamide gel electrophoresis to identify candidate polypeptides that might correspond to the enhancer core binding activity. Protein from individual pools (identified above each gel lane), along with molecular weight standards, was resuspended in sample buffer, boiled, and applied to a $10-20 \%$ polyacrylamide gradient gel. After electrophoresis, protein bands were visualized by silver staining (Wray et al. 1981). The following amounts of protein were loaded: nuclear extract, $4.2 \mu \mathrm{g}$; heat-soluble fraction, 4.3

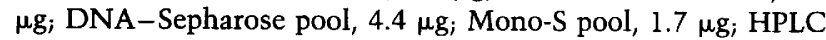
$\mathrm{C}_{4}$ fraction 18,0.25 $\mu \mathrm{g}$. Numbers at the left refer to sizes (in kilodaltons) of molecular-weight markers.

pattern on the MSV enhancer extends substantially upstream from its initial site of interaction within each 75-bp repeat (designated by stippled boxes in Fig. 5). Protein-DNA interaction in these secondary binding sites is also evidenced by DMS protections and enhancements. One of the enhancer repeats shows a marked DMS enhancement in this secondary domain, and the other repeat shows a DMS protection in the analogous region. These differences in DMS protection/enhancement are likely to result from DNA sequence differences that are known to exist in the distal halves of each MSV enhancer repeat (Van Beveren et al. 1981).

Figure 6 shows the pattern of DNase I and DMS protection established by gel-purified EBP20 on the SV40 enhancer. Like MSV, the SV40 enhancer consists of two repeats (72 bp in the case of SV40). At low protein concentrations EBP20 binds to a single domain of each enhancer repeat, and the sequence underlying this protected domain harbors the enhancer core homology $15^{\prime}$ TGTGGAAAG-3'). Moreover, EBP20 establishes distinct protections and enhancements of DMS alkylation in this domain. Like the situation in MSV, EBP20 binding leads to the protection of guanines at the second and fifth residues of the nonanucleotide, and hyperalkylation at the fourth residue. Finally, when excess EBP20 is introduced into the binding reaction, DNase I and DMS footprints are observed at two additional locations within the SV40 72-bp repeats. Weak binding is also observed at a site located immediately outside of the 72-bp repeats /toward the direction of the late transcription start site).

Figure 7 presents the pattern of EBP20 interaction with the $B$ (origin proximal) enhancer of polyoma virus. As in the cases of MSV and SV40, we again observe differences in the patterns of interaction of low and high concentrations of added protein. At 1.5-3.0 ng EBP20/ reaction, the DNase I footprint is restricted to a single location within the B enhancer, and this footprint encompasses the enhancer core homology. However, unlike MSV and SV40, the DNase I footprint on the polyoma virus enhancer is not centered atop the core sequence but instead extends asymmetrically toward the replication origin. This difference is also reflected in the pattern of DMS protection/enhancement established on the polyoma virus enhancer by EBP20. Although protein binding leads to hyperalkylation of the same guanine residue of the enhancer core consensus as in MSV and SV40, it fails to protect the second and fifth guanine residues that are protected in the other two cases. Furthermore, EBP20 establishes several alkylation enhancements, and one distinct protection, in the origin-proximal region of its primary binding site within the polyoma virus enhancer. Finally, when excess amounts of EBP20 are used in a binding reaction on the polyoma virus enhancer, additional domains, one on either side of the primary site of interaction, are detected.

The primary interactions of EBP20 and the three viral enhancers are summarized in Figure 8. The sites of strongest interaction correspond in each case to the locations of an enhancer core sequence. In all three cases, binding of the protein to these domains protects both DNA strands and leads to distinctive patterns of DMS alkylation. The patterns of protein-DNA interaction were more similar when MSV and SV40 were compared than when either of their patterns were compared with polyoma virus. Finally, in all three cases we observed additional domains of EBP20 interaction when protein input was increased to levels between 7.5 and $22.5 \mathrm{ng} / \mathrm{re}-$ action.

\section{Discussion}

In this study we have used a DNase I footprinting assay to track the biochemical fractionation of a rat liver protein that binds at specific sites within the enhancers of 


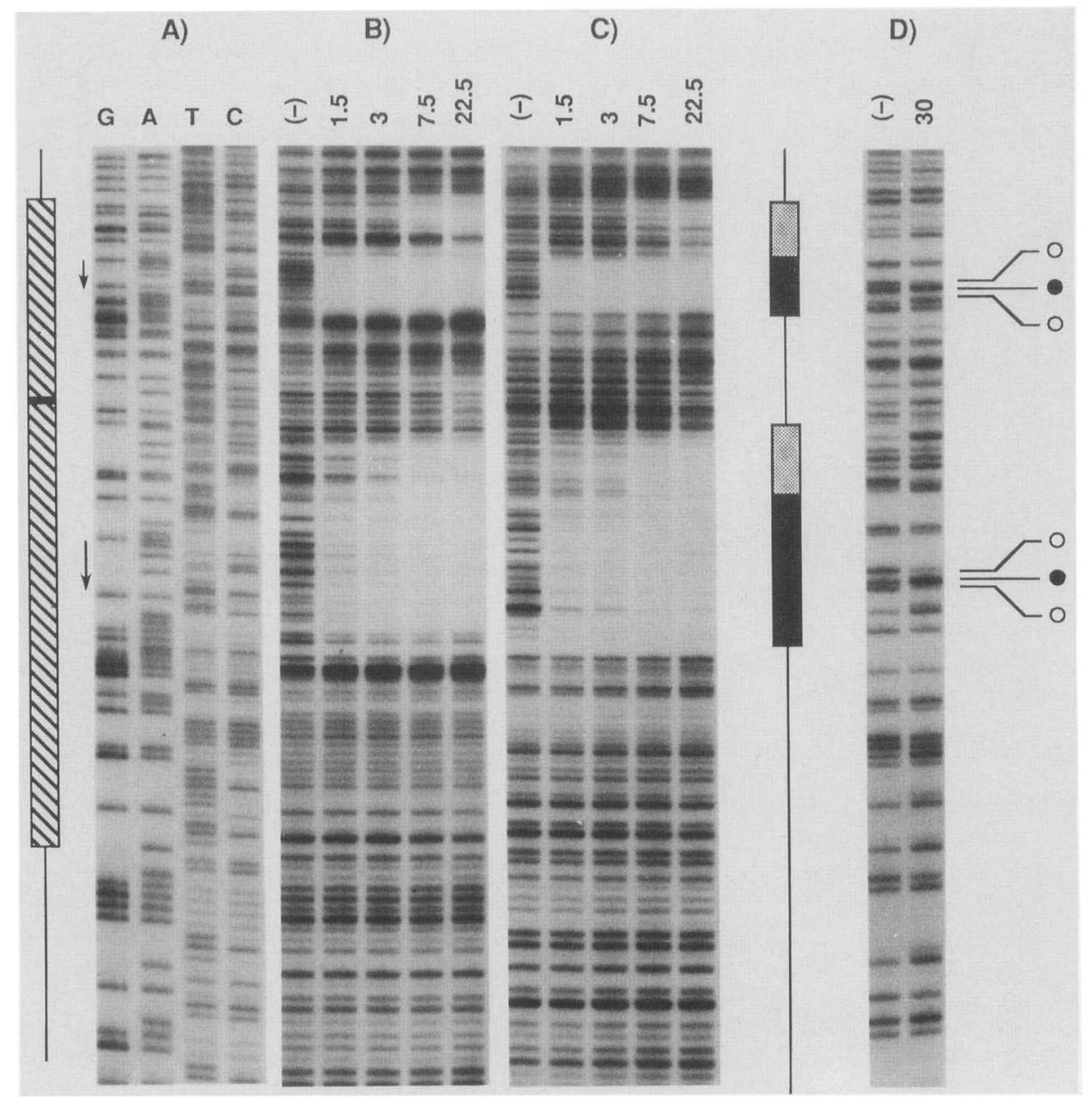

Figure 5. Binding of gel-purified EBP20 to the MSV enhancer. Gel-purified, renatured EBP20 protein was used in DNase I footprint titrations, and in a DMS methylation footprint experiment, using the MSV enhancer. A set of DNase I footprints using increasing amounts of EBP20 was performed for each strand of the MSV enhancer ( $B$ and $C)$. Each radiolabeled enhancer fragment was incubated with the indicated amount of EBP20, cleaved partially with DNase I, and electrophoresed on an $8 \%$ polyacrylamide/ $8 \mathrm{M}$ urea sequencing gel. Chemical sequencing tracks were run in parallel $(A)$. The numbers above the lanes shown in $B$ and $C$ specify the amount of EBP20 (in nanograms) delivered to each binding reaction. (-) refers to DNase I reactions carried out without added protein. The diagram at the left illustrates the location of enhancer sequences (hatched boxes) within the DNA probe. Arrows indicate the positions and orientations of enhancer core homologies. Regions of DNase I protection are shown schematically between $C$ and $D$. Solid bars represent domains of strong EBP20 binding; stippled bars show sites of weaker interaction. (D) Results of DMS methylation footprinting. Only the strand that contains guanines within the enhancer core sequence is shown. The DNA fragment was incubated alone or in the presence of $30 \mathrm{ng}$ of pure EBP20; binding reaction conditions were otherwise the same as for DNase I footprinting. After binding, the samples were treated with DMS to methylate exposed G residues (see Materials and methods). After isolation of the DNA, the fragments were cleaved with piperidine, dissolved in formamide loading buffer, and loaded onto the same sequencing gel that was used for the DNase I footprints. (O) Guanine residues protected from DMS upon EBP20 binding; ( 9 ) hypermethylated guanines. $(A, B)$ Bottom DNA strand and $(C, D)$ top strand of the MSV LTR DNA sequence as depicted in Fig. 8.

three animal viruses. These efforts have led to the identification of a $20-\mathrm{kD}$ polypeptide, termed EBP20, that appears to account for this DNA-binding activity. While we have been able to isolate a sufficient amount of homogeneously purified protein to perform qualitative studies on the manner in which EBP20 interacts with the MSV, SV40, and polyoma virus enhancers, we have not yet established an assay for the functional consequences of its binding. In the absence of such an assay, it is propitious to proceed cautiously with inferences as to the role of this protein in enhancer function. While we have not obtained evidence that EBP20 binding modu- lates the use of viral enhancers, it is known that the SV40 enhancer is functional in primary rat liver cell cultures (Tur-Kaspa et al. 1986). Thus, transcription factors capable of interacting with viral enhancers should be present in liver nuclei.

Given the aforementioned uncertainty as to the function of this protein, we have chosen to focus this discussion on the properties of EBP20 that are reasonably well established, rather than on speculations as to its potential role in gene activation. Some of the observations that have resulted from this work favor the notion that EBP20 is a transcriptional regulatory protein. For ex- 


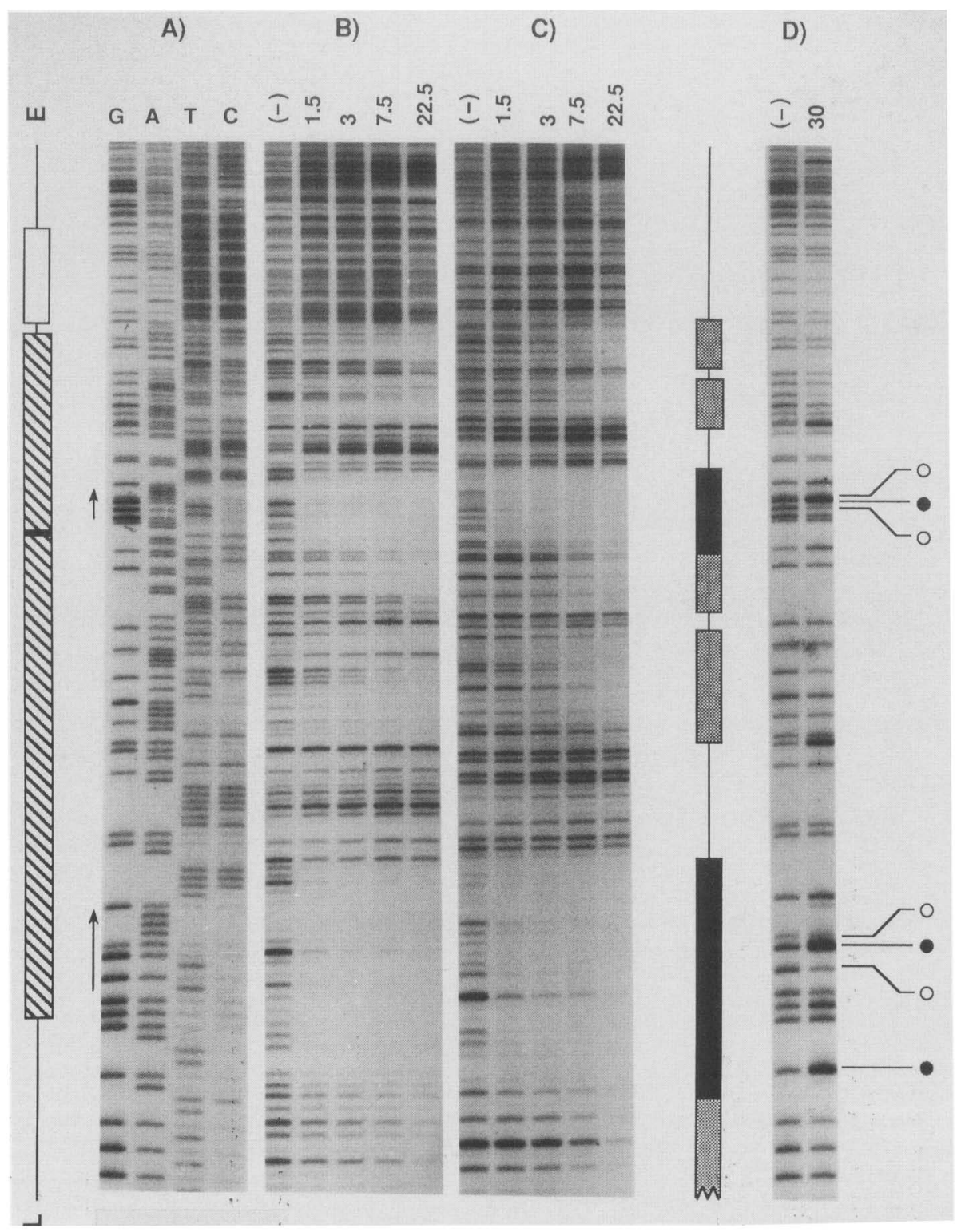

Figure 6. Binding of purified EBP20 to the SV40 enhancer. The experiments carried out to examine EBP20 interaction with the SV40 enhancer were identical to those presented in Fig. 5 for the MSV enhancer. The diagram on the left shows hatched boxes which represent the two 72-bp repeats of the SV40 enhancer, and an open box which indicates the 21-bp repeats /which constitute the Spl binding sites of the early promoter). $\mathrm{E}$ and $\mathrm{L}$ refer to the directions of early and late transcription. All other symbols are as explained in the legend to Fig. 5. The labeled DNA strand in panels $A, B$, and $D$ represents the top strand of SV40 as displayed in Fig. 8, and that in $C$ represents the bottom strand.

ample, it binds to DNA sequences that are known to play a cis-regulatory role in enhancer function, it appears to occur in rat liver nuclei at a comparatively low concentration, and it interacts with its binding sites within viral enhancers with reasonably high avidity (see subsequent discussion). Conversely, other observations on EBP20 are enigmatic. Why, for example, does EBP20 bind to so many different sites within the three viral enhancers?

We will first deal with the disconcerting properties of EBP20. As mentioned in the preceding paragraph, and documented in Figures 5-7, EBP20 binds not only to the "enhancer core sequence" shared by MSV, SV40, and polyoma virus, but also to regions adjacent to each core sequence. The sizes of these additional binding sites vary, their distances from the initial site of interaction vary, and we have been unable to establish any DNA sequence common to the secondary sites.

In attempting to evaluate the DNA sequences underlying these secondary binding sites, we noted that one of the two in the polyoma virus enhancer contains the pentanucleotide sequence $5^{\prime}$-CCAAT-3'. In another study on DNA-binding activities present in rat liver nuclei (Graves et al. 1986), we observed and partially char- 


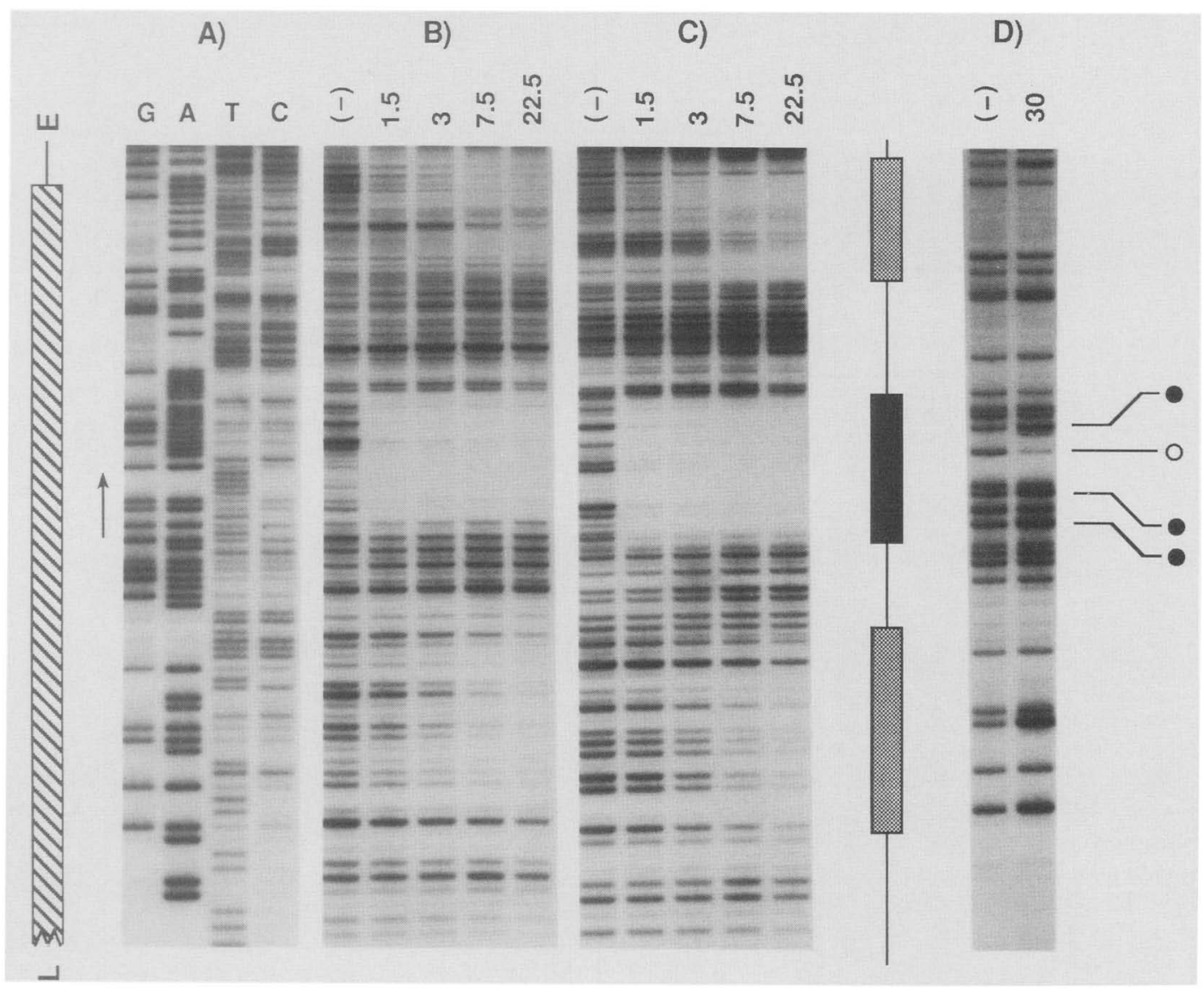

Figure 7. Binding of purified EBP20 to the polyoma virus B enhancer. Footprint experiments and symbols are the same as those of Figs. 5 and 6 . The hatched bar at the left indicates the position of the polyoma virus $B$ enhancer and the arrow denotes the location of its enhancer core homology. In $A, C$, and $D$ the labeled DNA strand represents the top strand of the polyoma virus sequence as shown in Fig. 8, and in $B$ the bottom DNA strand is labeled.

acterized an activity that was capable of binding to the CCAAT homologies of the herpes simplex virus (HSV) thymidine kinase $(t k)$ gene and the MSV LTR. That activity, termed CCAAT binding protein (CBP), like EBP20, was heat stable. Since the two activities shared this property, and since one of the secondary binding sites within the polyoma virus enhancer contained a perfect CCAAT homology, we tested gel-purified EBP20 for its ability to bind to the CCAAT homologies of the HSV $t k$ gene and the MSV LTR. The results of this test showed that EBP20 binds to both CCAAT homologies in a manner qualitatively indistinguishable from CBP /unpublished data). Thus, while formally unproven, it is possible that CBP binding activity is specified by the EBP20 polypeptide.

It is possible that all of the different binding interactions that we have observed between EBP20 and viral regulatory DNA sequences are functionally relevant. Alternatively, some of these interactions may simply be in vitro artifacts. While we cannot rigorously distinguish between these opposing interpretations, there are several reasons to believe that the latter is more apt to be correct. First, other studies on nuclear proteins that bind to the SV40 enhancer have been interpreted in favor of the interaction of a number of different proteins (Wil- deman et al. 1986). Were we to believe that all of the footprinted regions shown on the SV40 enhancer in Figure 6 were exclusively the targets of EBP20 binding, there would be little room left for interaction with other proteins. Second, the DNA sequences underlying these sites exhibit no readily apparent relationship. Since EBP20 is a comparatively small protein, it is difficult to imagine it containing a number of different DNAbinding domains.

It is possible that EBP20 interaction with secondary binding sites results from protein-protein cooperativity; that is, EBP20 binding at the enhancer core sequence might nucleate further interaction at secondary sites. Such a possibility has not been formally tested, but is amenable to experimentation. Perhaps the most likely explanation for the promiscuity of EBP20 binding is that the protein has suffered damage during purification, and that the damaged protein exhibits functionally irrelevant binding specificities. For example, the form of the protein that we have purified may have suffered proteolytic degradation. We hope to be able to resolve the immediate issue of proteolysis, and perhaps the larger issue of binding specificity, by developing antibodies specific to EBP20 and by cloning and studying the gene that encodes this protein. 
SV40

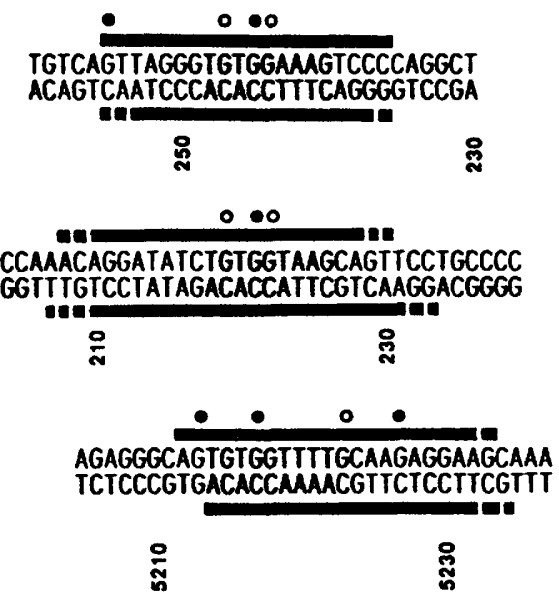

Figure 8. Summary of DNase I and DMS protection at the primary sites of EBP20 interaction within the SV40, MSV, and polyoma virus enhancers. DNA sequences are aligned such that the enhancer core homologies are in register. Solid lines represent the extents of DNase I protection on each DNA strand. Broken lines extend to the maximum limits of the footprints (up to the position of the first unprotected base). (O) Positions of guanine residues that are preferentially protected from DMS methylation after EBP20 binding; (O) guanines that are preferentially methylated following EBP20 binding. The stippled areas delineate the enhancer core homology of each virus. The numbers below each sequence refer to the following nucleotide numbering conventions: SV40 (Buchanan et al. 1981); MSV (Van Beveren et al. 1981); polyoma virus (Deininger et al. 1980).

While it is clear that there are uncertainties regarding the functional role of EBP20, there are also a number of reasons to believe that it will be an interesting protein to study. It appears to be a rare constituent of rat liver nuclei. As summarized in Table 1, we calculate a $0.7 \%$ yield of EBP20 activity through the fractionation protocol that was used to purify it. If we estimate that $50 \%$ of the protein present in the HPLC $\mathrm{C}_{4}$ fraction 18 is $\operatorname{EBP} 20(1.3 \mu \mathrm{g})$, and assume that the reduction in activity through the purification procedure was entirely due to physical loss of protein, then the starting material contained $186 \mu \mathrm{g}$ of EBP20. This amount of a $20-\mathrm{kD}$ polypeptide corresponds to $5.8 \times 10^{15}$ molecules; accordingly, each of the $4 \times 10^{10}$ rat liver nuclei with which the purification was started contained roughly 100,000 molecules of EBP20. This intracellular concentration is comparable to that estimated for the transcription factor $\mathrm{Sp} 1$ in HeLa cells (R. Tjian, pers. comm.). Consistent with these calculations of the rarity of EBP20, it is undetectable by silver staining of one-dimensional SDS-polyacrylamide gels in our crude nuclear extract (see Fig. 4).

The facts that EBP20 is rare, yet binds in crude extracts to determinants within viral enhancers, suggest that it may recognize such sites avidly. Since we have tentatively identified the polypeptide that accounts for this activity, we can, for the first time, establish a rough calculation of its concentration in a binding reaction. This calculation, in turn, facilitates an estimation of the molarity of the protein when it half-maximally occupies its binding site on the polyoma virus enhancer core. According to these calculations we estimate a dissociation constant of $9 \times 10^{-10} \mathrm{M}$ (see Table 1). In arriving at this estimation we assumed that $50 \%$ of the protein in the $\mathrm{C}_{4}$ fraction 18 is the $20-\mathrm{kD}$ species, that all of it is active, and that the protein acts as a monomer. If either of the latter two assumptions is incorrect, our calculation of the in vitro avidity of the $20-\mathrm{kD}$ polypeptide for its binding site within the polyoma virus enhancer would represent an underestimate.

In closing we point out the possibility that we may not, as yet, be aware of the true binding site of EBP20. Unlike most other studies of this nature, we have used a differentiated tissue as a source of nuclear proteins for footprint analysis and subsequent purification. It is entirely possible that EBP20 is a liver-specific protein, and that the binding sites that we have observed in viral enhancers are adventitious relatives of the cellular sites of EBP20 interaction. If this is the case, we find it remarkable, and potentially interesting, that the protein interacts selectively with important transcriptional regulatory sequences of viral genes.

\section{Materials and methods}

Recombinant plasmids and labeling of enhancer DNA fragments

Plasmids containing cloned enhancer sequences to be radiolabeled for use in footprinting experiments were constructed as follows.

SV40 A plasmid was obtained which carried the SV40 enhancer and early promoter fused (at nucleotide -34 relative to the start site of early SV40 transcription) to the HSV $t k$ gene (at nucleotide -32 relative to the $t k$ mRNA start site). A restriction fragment extending from the KpnI site in SV40 to the BgIII site in the $t k$ gene was excised from this plasmid and ligated into the vector pEMBL18, which had been digested with KpnI and BamHI. To generate end-labeled DNA for footprint experiments, the resultant plasmid (p18SVE/tk) was cleaved and labeled with ${ }^{32} \mathrm{P}$ at the HindIII site either by replacement of the $5^{\prime}$ terminal phosphate or by enzymatic fill-in from the $3^{\prime}$ hydroxyl. The plasmid DNA was then redigested with $E c o R I$ and the labeled 400-bp fragment containing the enhancer was purified by agarose gel electrophoresis for use in footprints.

Polyoma virus The 137-bp PvuII restriction fragment which defines the polyoma "B enhancer" (Herbomel et al. 1984) was inserted into pEMBL18 as follows. A plasmid carrying an XhoI linker at the PvuII site located at nucleotide 5290 (Deininger et al. 1980), and including the entire polyoma enhancer region, was digested with PvuII and XhoI, liberating a 140-bp fragment. This DNA was then inserted between the SmaI and SalI sites of pEMBL18. The resultant plasmid, p18PyEB, was radiolabeled at the HindIII site as described for p18SVE/tk, and digested with EcoRI to produce a 175-bp fragment that was used for DNase I footprints.

MSV A plasmid containing a 3' deletion of the MSV LTR ending at nucleotide -93 (Graves et al. 1985) was radiolabeled at the HindIII site which defines the deletion end point. Subsequent digestion with EcoRI released a 600-bp DNA fragment that was gel-purified and used for footprint experiments. 


\section{Preparation of rat liver nuclear extract}

Crude rat liver nuclear extract (RLNE) was prepared from male Sprague-Dawley rats as described by Graves et al. (1986) with the following modifications: (1) the protease inhibitor benzamidine (Aldrich) was added to all buffers used in the nuclear isolation procedure at a final concentration of $2 \mathrm{~mm} ;(2)$ after the ammonium sulfate precipitation step, the redissolved protein was desalted by passage over a $250-\mathrm{ml}$ P6DG column (BioRad), equilibrated, and developed in TGMEDK100 buffer $25 \mathrm{mM}$ Tris- $\mathrm{HCl}, \mathrm{pH} 7.9,10 \% \mathrm{vol} / \mathrm{vol}$ glycerol, 5, $\mathrm{mM} \mathrm{MgCl}_{2}$, $0.1 \mathrm{~mm}$ EDTA, $1 \mathrm{~mm}$ DTT, $100 \mathrm{~mm} \mathrm{KCl}, 0.2 \mathrm{~mm}$ PMSF).

\section{Protein purification}

Except where indicated, the standard column buffer was TGMED, with the $\mathrm{KCl}$ concentration adjusted as specified. Rat liver nuclear extract (RLNE) prepared from 700 grams of liver was distributed to $30-\mathrm{ml}$ glass centrifuge tubes and heated to $85^{\circ} \mathrm{C}$ with constant agitation. After being held at this temperature for $5 \mathrm{~min}$, the tubes containing the crude RLNE were immersed in ice water and the precipitated protein was removed by centrifugation for $10 \mathrm{~min}$ at $10,000 \mathrm{rpm}$ in a Sorval SS-34 rotor. The supernatant (heat-soluble fraction) was applied directly to a $15-\mathrm{ml}$ bed volume DNA-Sepharose column (DNASepharose was prepared using salmon sperm DNA as described in Graves et al. 1986). After loading, the column was washed with $50 \mathrm{ml}$ of TGMEDK200, and then developed by a 5-column volume linear gradient from 0.2 to $0.8 \mathrm{M} \mathrm{KCl}$. The activity peak was identified by DNase I footprinting, pooled, dialyzed for $2 \mathrm{hr}$ against TGMEDK100, and applied to an FPLC HR5/5 Mono-S column (Pharmacia). The column was washed with $8 \mathrm{ml}$ of TGMEDK 150 and the bound protein eluted in a $20-\mathrm{ml}$ linear gradient from 0.15 to $0.6 \mathrm{M} \mathrm{KCl}$. The activity eluting from Mono-S was identified by DNase I footprinting, pooled, and loaded onto an Aquapore butyl HPLC column $1100 \times 2.1 \mathrm{~mm}$; Brownlee Labs|. The column was washed with $20 \%$ acetonitrile containing $0.4 \% \mathrm{~N}$-ethyl morpholinium acetate (NEMAC, pH 6.5 ), and developed with a $30-\mathrm{ml}$ gradient from $20 \%$ to $50 \%$ acetonitrile in $0.4 \%$ NEMAC ( $\mathrm{pH} 6.5$ ). The flow rate was 0.5 $\mathrm{ml} / \mathrm{min}$; 1-ml fractions were collected, assayed, and stored at $-80^{\circ} \mathrm{C}$

\section{Gel purification of EBP2O}

Protein from the Mono-S fraction was concentrated by trichloroacetic acid precipitation and size-separated by electrophoresis on a $10-20 \%$ polyacrylamide gradient gel (Laemmli 1970). Protein bands were stained with Coomassie Brilliant Blue, excised from the gel, and electroeluted in the presence of SDS according to the method of Hunkapiller et al. (1983). After addition of 20 $\mu \mathrm{g}$ bovine serum albumin (BSA) the protein was precipitated by the addition of 4 volumes of cold acetone and recovered by centrifugation in an Eppendorf microcentrifuge. Pelleted protein was washed with $80 \%$ acetone, and each sample was then subjected to a renaturation regimen performed according to the procedure of Hager and Burgess (1980). The protein pellets were resuspended in $100 \mu \mathrm{l}$ of $6 \mathrm{M}$ guanidine- $\mathrm{HCl}$ in dilution buffer $(0.05 \mathrm{M}$ Tris $-\mathrm{HCl}, \mathrm{pH} 7.9,0.15 \mathrm{M} \mathrm{NaCl}, 0.1 \mathrm{~mm}$ EDTA, $1 \mathrm{~mm}$ DTT, $20 \%$ glycerol, and $100 \mu \mathrm{g} / \mathrm{ml} \mathrm{BSA}$. After adding an equal volume of dilution buffer, the guanidine was gradually removed by dialyzing the samples against dilution buffer lacking BSA at $4^{\circ} \mathrm{C}$ for $12 \mathrm{hr}$.

\section{DNase I and DMS footprinting}

DNase I footprint reactions were carried out as described by Graves et al. (1986). One microgram of poly dI : dC competitor
DNA (Sigma) was added to each footprint assay of fractions preceding the DNA-Sepharose column. At all subsequent steps, 50 ng of competitor was added to each binding reaction. DMS footprints were performed by treating the same binding reactions with $50 \mu$ lof DMS diluted $1: 200$ into the standard DMS buffer used for chemical DNA sequencing (Maxam and Gilbert 1980). After $2 \mathrm{~min}$ at $25^{\circ} \mathrm{C}$, reactions were quenched by the addition of $25 \mu$ l DMS stop (Maniatis et al. 1982). Probe DNA was extracted with phenol/chloroform and precipitated with ethanol. The samples were thereafter treated as outlined in the chemical DNA sequencing technique of Maxam and Gilbert (1980).

\section{Acknowledgments}

We wish to thank Clarke Riley for his generous assistance in performing the HPLC separation, Steven Triezenberg for providing a recombinant plasmid containing the polyoma virus enhancer, and Robert Tjian for providing a recombinant plasmid containing the SV40 enhancer. We also thank Steven Triezenberg, Kelly LaMarco, and Frank Tufaro for critical reading of the manuscript, Bob Kingsbury for his excellent technical assistance, Chris Hug and Jimmy Montoya for extensive help in the homogenization of rat liver and purification of nuclei, and Robert Tjian for communicating unpublished observations. P.F.J. was supported by a Damon Runyon-Walter Winchell Cancer Fund Fellowship (DRG-780). B.J.G. was supported by a postdoctoral fellowship from the Carnegie Corporation. W.H.L. is a Medical Scientist Scholar of the Life and Health Insurance Medical Research Fund. This work was otherwise funded by a research grant to S.L.M. from the National Institutes of Health.

\section{References}

Augereau, P. and P. Chambon, 1986. The mouse immunoglobulin heavy-chain enhancer: Effect on transcription in vitro and binding of proteins in HeLa and lymphoid B cell extracts. EMBO I. 5: 1791-1797.

Banerii, J., S. Rusconi, and W. Schaffner. 1981. Expression of a beta-globin gene is enhanced by remote SV40 DNA sequences. Cell 27: 299-308.

Banerii, J., L. Olson, and W. Schaffner. 1983. A lymrhocyte-specific enhancer is located downstream of the joining region in immunoglobulin heavy chain genes. Cell 33: 729-740.

Bradford, M.M. 1976. A rapid and sensitive method for the quantitation of microgram quantities of protein utilizing the principle of protein-dye binding. Anal. Biochem. 72: 248254.

Brenowitz, M., D.F. Senear, M.A. Shea, and G.K. Ackers. 1986. "Footprint" titrations yield valid thermodynamic isotherms. Proc. Natl. Acad. Sci. 83: 8462-8466.

Briggs, M.R., J.T. Kadonaga, S.P. Bell, and R. Tjian. 1986. Purification and biochemical characterization of the promoterspecific transcription factor, Sp1. Science 234: 47-52.

Buchanan, A.R., L. Burnett, and P. Berg. 1981. The SV40 nucleotide sequence. In Molecular biology of tumor viruses, DNA tumor viruses, 2nd ed. (ed. J. Tooze), p. 799-841. Cold Spring Harbor Laboratory, Cold Spring Harbor, New York.

Chandler, V.L., B.A. Maler, and K.R. Yamamoto. 1983. DNA sequences bound specifically by glucocorticoid receptor in vitro render a heterologous promoter hormone responsive in vivo. Cell 33: 489-499.

Church, G.M., A. Ephrussi, W. Gilbert, and S. Tonegawa. 1985. Cell type specific contacts to immunoglobulin enhancers in nuclei. Nature 313: 798-801. 
Davidson, I., C. Fromental, P. Augereau, A. Wildeman, M. Zenke, and P. Chambon. 1986. Cell-type specific protein binding to the enhancer of simian virus 40 in nuclear extracts. Nature 323: $544-548$.

Deininger, P., A. Esty, P. LaPorte, H. Hore, and T. Friedmann. 1980. The nucleotide sequence and restriction enzyme sites of the polyoma genome. Nucleic Acids Res. 8: 855-860.

Ephrussi, A., G.M. Church, S. Tonegawa, and W. Gilbert. 1985. B lineage-specific interactions of an immunoglobulin enhancer with cellular factors in vivo. Science 227: 134-140.

Fromm, M. and P. Berg. 1983. Simian virus 40 early- and lateregion promoter functions are enhanced by the 72-base-pair repeat inserted at distant locations and inverted orientations. Mol. Cell. Biol. 3: 991-999.

Fujimura, F.K. 1986. Nuclear activity form F9 embryonal carcinoma cells binding specifically to the enhancers of wildtype polyoma virus and PyEC mutant DNAs. Nucleic Acids Res. 14: 2845-2861.

Galas, D. and A. Schmitz. 1978. DNase footprinting: A simple method for the detection of protein-DNA binding specificity. Nucleic Acids Res. 5: 3157-3170.

Gillies, S.D., S.L. Morrison, V.T. Oi, and S. Tonegawa. 1983. A tissue-specific transcriptional enhancer element is located in the major intron of a rearranged immunoglobulin heavy chain gene. Cell 33: 717-728.

Graves, B.J., R.N. Eisenman, and S.L. McKnight. 1985. Delineation of transcriptional control of signals within the Moloney murine sarcoma virus long terminal repeat. Mol. Cell. Biol. 5: 1948-1958.

Graves, B.J., P.F. Johnson, and S.L. McKnight. 1986. Homologous recognition of a promoter domain common to the MSV LTR and the HSV tk gene. Cell 44: 565-576.

Hager, D.A. and R.R. Burgess. 1980. Elution of proteins from sodium dodecyl sulfate-polyacrylamide gels, removal of sodium dodecyl sulfate, and renaturation of enzymatic activity: Results with sigma subunit of Escherichia coli RNA polymerase, wheat germ DNA topoisomerase, and other enzymes. Anal. Biochem. 109: 76-86.

Herbomel, P., B. Bourachot, and M. Yaniv. 1984. Two distinct enhancers with different cell specificities coexist in the regulatory region of polyoma. Cell 39: 653-662.

Herr, W. and J. Clarke. 1986. The SV40 enhancer is composed of multiple functional elements that can compensate for one another. Cell 45: 461-470.

Herr, W. and Y. Gluzman. 1985. Duplications of a mutated simian virus 40 restore its activity. Nature 313: 711-714.

Hunkapillar, M.W., E. Lujan, F. Ostrander, and L.E. Hood. 1983. Isolation of microgram quantities of proteins from polyacrylamide gels for amino acid sequence analysis. Methods Enzymol. 91: 227-236.

Laemmli, U.K. 1970. Cleavage of structural proteins during the assembly of the head of bacteriophage T4. Nature 227: 680685.

Levinson, B., G. Khoury, G. Vande Woude, and P. Gruss. 1982. Activation of SV40 genome by 72-base pair tandem repeats of Moloney sarcoma virus. Nature 295: 568-572.

Maeda, H., D. Kitamura, A. Kudo, K. Araki, and T. Watanabe. 1986. Trans-acting nuclear protein responsible for induction of rearranged human immunoglobulin heavy chain gene. Cell 45: 25-33.

Maniatis, T., E.F. Fritsch, and J. Sambrook. 1982. Molecular cloning: A laboratory manual. Cold Spring Harbor Laboratory, Cold Spring Harbor, New York.

Maxam, A.M. and W. Gilbert. 1980. Sequencing end-labeled DNA with base-specific chemical cleavages. Methods Enzymol. 65: 499-560.

Mercola, M., J. Goverman, C. Mirell, and K. Calame. 1985. Im- munoglobulin heavy chain enhancer requires one or more tissue specific factors. Science 227: 266-270.

Moreau, P., R. Hen, B. Wasylyk, R. Everett, M.P. Gaug, and P. Chambon. 1981. The SV40 72 base pair repeat has a striking effect on gene expression both in SV40 and other chimeric recombinants. Nucleic Acids Res. 9: 6047-6068.

Ohlsson, H. and T. Edlund. 1986. Sequence-specific interactions of nuclear factors with the insulin gene enhancer. Cell 45: 35-44.

Ostapchuk, P., J.F.X. Diffley, J.T. Bruder, B. Stillman, A.J. Levine, and P. Hearing. 1986. Interaction of a nuclear factor with the polyomavirus enhancer region. Proc. Natl. Acad. Sci. 83: 8550-8554.

Payvar, F., D. DeFranco, G.L. Firestone, B. Edgar, O. Wrange, S. Okret, J.-A. Gustafsson, and K.R. Yamamoto. 1983. Sequence-specific binding of glucocorticoid receptor to MTV DNA at sites within and upstream of the transcribed region. Cell 35: 381-392.

Peterson, C.L., K. Orth, and K.L. Calame. 1986. Binding in vitro of multiple cellular proteins to immunoglobulin heavychain enhancer DNA. Mol. Cell. Biol. 6: 4168-4178.

Piette, J., M.-H. Kryszke, and M. Yaniv. 1985. Specific interaction of cellular factors with the B enhancer of polyoma virus. EMBO I. 4: 2675-2685.

Queen, C. and D. Baltimore. 1983. Immunoglobulin gene transcription is activated by downstream sequence elements. Cell 33: $741-748$.

Queen, C. and J. Stafford. 1984. Fine mapping of an immunoglobulin gene activator. Mol. Cell. Biol. 4: 1042-1049.

Sassone-Corsi, P. and E. Borrelli. 1986. Transcriptional regulation by trans-acting factors. Trends Genet. 2: 215-219.

Sassone-Corsi, P., J.P. Dougherty, B. Wasylyk, and P. Chambon. 1984. Stimulation of in vitro transcription from heterologous promoters by the simian virus 40 enhancer. Proc. Natl. Acad. Sci. 81: 308-312.

Scholer, H.R. and P. Gruss. 1984. Specific interactions between enhancer containing molecules and cellular components. Cell 36: 403-411.

1985. Cell type-specific transcriptional enhancement in vitro requires the presence of trans-acting factors. $E M B O F$. 4: 3005-3013.

Sen, R. and D. Baltimore. 1986. Multiple nuclear factors interact with the immunoglobulin enhancer sequences. Cell 46: 705-716.

Sergeant, A., D. Bohmann, H. Zentgraf, H. Weiher, and W. Keller. 1984. A transcription enhancer acts in vitro over distances of hundreds of base-pairs on both circular and linear templates but not on chromatin-reconstituted DNA. J. Mol. Biol. 180: 577-600.

Tur-Kaspa, R., L. Teicher, B.J. Levine, A.I. Skoultchi, and D.A. Schafritz. 1986. Use of electroporation to introduce biologically active foreign genes into primary rat hepatocytes. Mol. Cell Biol. 6: 716-718.

Van Beveren, C., F. van Straaten, J.A. Galleshaw, and I.M. Verma. 1981. Nucleotide sequence of the genome of a murine sarcoma virus. Cell 27: 97-108.

Walker, M.D., T. Edlund, A.M. Boulet, and W.J. Rutter. 1983. Cell-specific expression controlled by the $5^{\prime}$-flanking region of insulin and chymotrypsin genes. Nature 306: 557-561.

Weiher, H., M. Konig, and P. Gruss. 1983. Multiple point mutations affecting the simian virus 40 enhancer. Science 219: 626-631.

Wildeman, A.G., P. Sassone-Corsi, T. Grundstrom, M. Zenke, and P. Chambon. 1984. Stimulation of in vitro transcription from the SV40 early promoter by the enhancer involves a specific trans-acting factor. EMBO. I. 3: 3129-3133.

Wildeman, A.G., M. Zenke, C. Schatz, M. Wintzerith, T. 
Johnson et al.

Grundstrom, H. Matthes, K. Takahashi, and P. Chambon. 1986. Specific protein binding to the simian virus 40 enhancer in vitro. Mol. Cell. Biol. 6: 2098-2105.

Wray, W., T. Boulikas, V.P. Wray, and R. Hancock, 1981. Silver staining of proteins in polyacrylamide gels. Anal. Biochem. 118: 197-203.

Zenke, M., T. Grundstrom, H. Matthes, M. Wintzerith, C. Schatz, A. Wildeman, and P. Chambon. 1986. Multiple sequence motifs are involved in SV40 enhancer function. EMBO. J. 5: 387-397. 


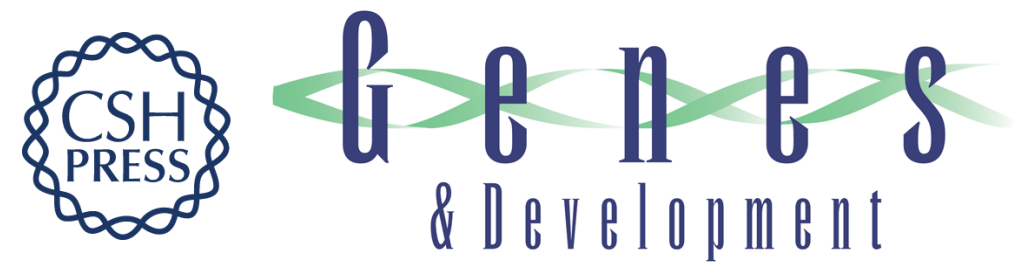

\section{Identification of a rat liver nuclear protein that binds to the enhancer core element of three animal viruses.}

P F Johnson, W H Landschulz, B J Graves, et al.

Genes Dev. 1987, 1:

Access the most recent version at doi:10.1101/gad.1.2.133

$\begin{array}{ll}\text { References } & \text { This article cites } 49 \text { articles, } 13 \text { of which can be accessed free at: } \\ \text { http://genesdev.cshlp.org/content/1/2/133.full.html\#ref-list-1 }\end{array}$

License

Email Alerting Receive free email alerts when new articles cite this article - sign up in the box at the top Service right corner of the article or click here.

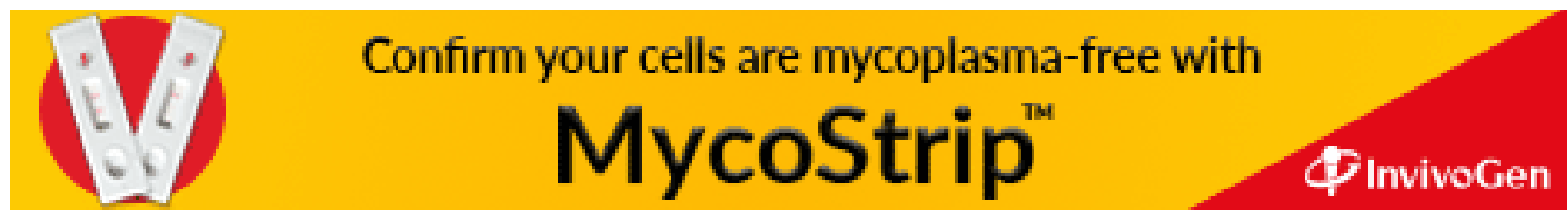

